\title{
Comparative Study between Linear-Interpolation and Stress-Block Methods of Composite Design Using Cold-Formed Steel Section
}

\author{
M. M. Lawan', P. N. Shek ${ }^{2, *}$, M. M. Tahir ${ }^{2}$ \\ ${ }^{1}$ Department of Civil Engineering, Faculty of Engineering, Kano University of Science and Technology, Wudil, \\ Kano State, Nigeria \\ ${ }^{2}$ UTM Construction Research Centre, Institute for Smart Infrastructure and Innovative Construction, Faculty of Civil Engineering, \\ Universiti Teknologi Malaysia, 81310, Johor Baharu, Malaysia \\ *Corresponding author Email: shekpoingian@utm.my
}

\begin{abstract}
For decades, Hot Rolled Steel (HRS) section was in use in construction of buildings and bridges. The simple reason is that the use of HRS section in composite systems is well established by standard rules and their design necessities as provided in the codes. In this paper, the use of doubly oriented back-to-back Cold-Formed Steel (CFS) section coupled with bolted shear connectors in composite floor system was demonstrated. The bolted system of shear connector provides an alternative to headed stud shear connector with CFS section as welding of the stud connector is practically not feasible on CFS section because of its thinness nature. The loading system u sed was fourpoint bending test to determine the flexural strength capabilities of the composite floor system. The resulting composite floor system has proven to provide adequate strength and stiffness properties under the applied loads. The results have shown that the theoretical value of flexural capacities calculated agrees reasonably well with the experimental values. In conclusion, the composite floor system can be used in small and medium size buildings, as well as in light weight construction industries.
\end{abstract}

Keywords: Cold-formed steel section; linear-interpolation method; stress-block method; composite design; composite floor system

\section{Introduction}

Steel and concrete composite beam system has been in existence as a structural member in buildings and bridges for decades [1] with the use of Hot Rolled Steel (HRS) section, headed stud shear connectors and conventional vibrated concrete. In composite beam system, the shear connection between steel and concrete slab is fundamentally significant, because it resists separation between the two components and it also improves longitudinal shear transmission [2]. The most common form of shear connection in composite beams system is the use of mechanical devices referred as shear connectors [3]. Conventional shear connection mechanism with headed stud shear connectors is the most widely used system, in which the stud connectors are welded on the steel flange and encased in concrete to provide the composite action [4] According to Eurocode 4 [5], the strength and ductility of shear connectors can be obtained from push-out test if it's not established in standard codes.

A significant number of published research studies [6-14] on using different types of shear connectors with varieties of steel sections demonstrated the potentials of the system on providing the composite action required. According to Irwan et al., [11], distance from the neutral axis to the top of the concrete deck is minimized when resorting to composite construction of Cold-Formed Steel (CFS) section and a concrete deck slab. Orienting two CFS section back-to-back suppresses lateral-torsional and lateral-distortional buckling to a lesser extent and compressive bending stresses are also reduced [11]. The two fold benefits manifested by the system encourage the use of CFS sections in a broader range of structural applications.

Therefore, in this paper, the use of doubly oriented back-to-back CFS section coupled with bolted shear connectors in composite floor system is demonstrated. Moreover, a comparative study on the methods involved in computing the flexural capacities is also demonstrated. The structural capability if established, will significantly offer a step forward for its usage in the construction of small and medium size buildings, as well as in light weight construction industries

\section{Methodology}

The methodology section is to present the materials and the tests conducted in order to obtain their actual strength properties as well as the composite beam flexural test conducted as stated in subsections $2.1,2.2$ and 2.3 respectively.

\subsection{Materials and Their Properties}

Materials used in the study are CFS lipped channel section with web depth of $250 \mathrm{~mm}$, flange width of $75 \mathrm{~mm}$ and lipped depth of $18 \mathrm{~mm}$ with a thickness of $2.3 \mathrm{~mm}$; bolted shear connectors of M16, M14 and M12 of grade 8.8; welded wire fabric mesh A142 of $6 \mathrm{~mm}$ thick spaced $200 \mathrm{~mm} \times 200 \mathrm{~mm}$ of deformed bar of strength $460 \mathrm{~N} / \mathrm{mm}^{2}$; and SCC of grade $40 \mathrm{~N} / \mathrm{mm}^{2}$ respectively. The materials were tested to obtain their actual strength properties 
by tensile, compression and modulus of elasticity tests respectively. The materials properties are presented in Table 1.

Table 1: Results of Materials Properties Test

\begin{tabular}{|c|c|c|}
\hline Materials & $\begin{array}{c}\text { Average Yield } \\
\text { Strength } \\
\boldsymbol{f}_{\boldsymbol{y}}, \\
\left(\mathbf{N} / \mathbf{m m}^{\mathbf{2}}\right)\end{array}$ & $\begin{array}{c}\text { Average } \\
\text { Ultimate Strength } \\
\boldsymbol{f}_{\boldsymbol{u}}, \\
\left(\mathbf{N} / \mathbf{m m}^{\mathbf{2}}\right)\end{array}$ \\
\hline CFS & 487.4 & 523.9 \\
\hline M16 Bolt & 468.0 & 897.0 \\
\hline M14 Bolt & 758.0 & 847.0 \\
\hline M12 Bolt & 761.0 & 843.0 \\
\hline Welded wire fabric & 502.4 & 594.9 \\
\hline & Average & Average \\
& Compressive Strength & Modulus of Elasticity \\
& $f_{c u}$, & $E$, \\
$\left(\mathrm{N} / \mathrm{mm}^{2}\right)$ & 35.4 \\
\hline Concrete & 40.7 & \\
\hline
\end{tabular}

\subsection{CFS-Concrete Composite Beam Specimens}

The composite beam specimen shown in (Fig. 1) was $4500 \mathrm{~mm}$ in length (1), and $4200 \mathrm{~mm}$ efficiently spanned (le) between the end supports. Slab width (Be) and depth (d) were $1500 \mathrm{~mm}$ and 75 $\mathrm{mm}$ respectively. The doubly I- beam section of the CFS was formed by back-to-back orientation using self-drilling screws of $5.8 \mathrm{~mm}$ diameter. Bolt holes of $17 \mathrm{~mm}, 15 \mathrm{~mm}$ and $13 \mathrm{~mm}$ diameter were drilled on the upper flanges of the CFS section. But, for the shear connection to be provided between the concrete slab and the CFS section, bolted shear connectors of M16, M14 and M12 were installed through the holes with single nut and washer at top and bottom of the flanges at longitudinal spacing of $250 \mathrm{~mm}$ and $300 \mathrm{~mm}$ respectively, and at $75 \mathrm{~mm}$ laterally spaced. The wire fabric mesh was installed to prevent creeping and shrinkage of the concrete.

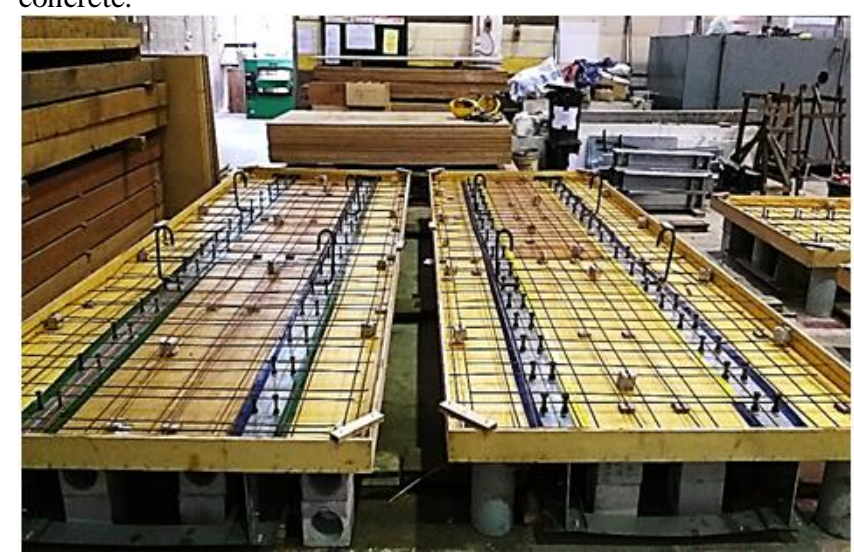

(a) Specimens formwork

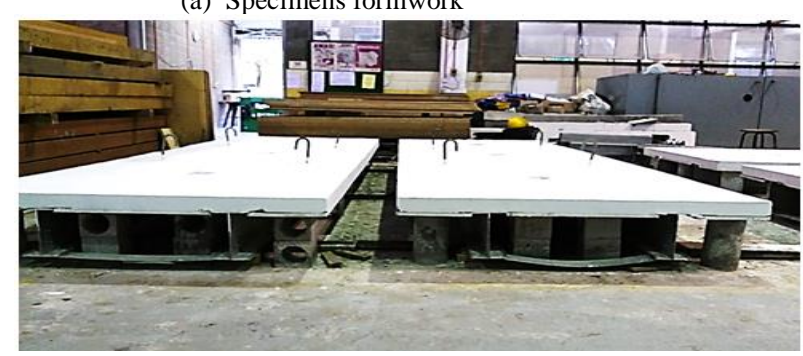

(b) Finished specimens

Fig. 1: Full-scale test specimens

\subsection{Instrumentation, Test Set-Up and Procedure}

The tests of the composite specimens were conducted using DARTEC jack machine with a load capacity of $2000 \mathrm{kN}$. The test specimens were subjected to flexural test using four point bending set up, where the load was applied at a shear span of $1050 \mathrm{~mm}$ away from the supports. The four-point bending test is a flexural test which provides pure bending moment section without any shear force occurring along the section. The specimen was placed as simply supported beam structure as shown in (Fig. 2).
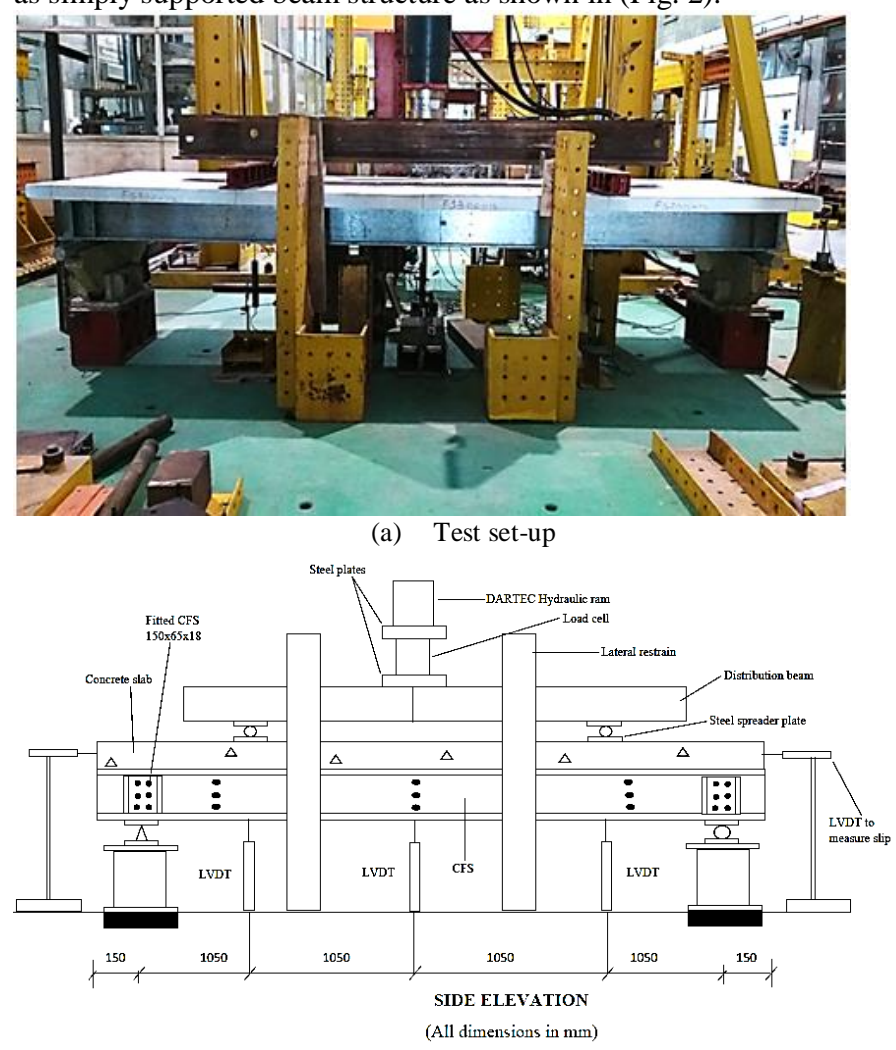

(b) Schematic diagram of test set-up

Fig. 2: Composite beam test arrangement

Possible deflections of the specimen were monitored at mid and quarter spans underneath the bottom flanges of the section (CFS) respectively, using Linear Variable Displacement Transducers (LVDT's). Strains in the specimen were also checked on top of the concrete slab and beneath the bottom flanges of the section (CFS) using strain gauges. Data logger was linked to the LVDT's and strain gauges for data collection. Due to possible high level of stresses at the supports, CFS failure may occur prematurely; thus, that was prevented using a section (CFS) with dimensions of 150 $\mathrm{mm} \times 65 \mathrm{~mm}$ x $18 \mathrm{~mm}$ of thickness $2.3 \mathrm{~mm}$ (See Fig. 2 (b)) fitted to the supports positions of the main CFS section. Load from the machine through the distribution beam on the specimen was maintained at a rate of $0.2 \mathrm{kN} / \mathrm{s}$, which was transferred to the concrete slab via the positioned line load beams on the specimen (see Fig. 2(b)).

The positioned line load beams were placed on a steel spreader plates of $200 \mathrm{~mm} \times 150 \mathrm{~mm} \times 12 \mathrm{~mm}$ thick, to make the load applied to be as point load on the concrete. The specimen was loaded to about $15 \%$ of its projected failure capacity and then released to zero level; this was made to guarantee that the instrumentation procedure was all right and the specimen was in stability state prior to the proper testing. The specimen was then loaded again above the $15 \%$ of its projected failure capacity to its ultimate level of failure. Load on the specimen was further increased until failure occurred. Specimen failure was considered when a significant fall in the load applied or a large deformation of the specimen was noticed. During the test, lateral restrains were provided, to prevent the specimen from felling prematurely due to lateral torsional buckling.

\section{Results and Discussion}

Experimental results of the beam specimens are presented in Table 2 . The ultimate moments were obtained by multiplying the ultimate shear values with a shear span value of $1.05 \mathrm{~m}$ (i.e. 1050 $\mathrm{mm})$. 


\begin{tabular}{|c|c|c|c|c|c|}
\hline $\begin{array}{l}\text { Specimen } \\
\text { ID }\end{array}$ & $\begin{array}{c}\text { f }_{\text {ck }} \text { at test day } \\
\left(\mathrm{N} / \mathrm{mm}^{2}\right)\end{array}$ & $\begin{array}{c}\text { Ultimate load, } \\
\mathbf{P}_{\mathbf{u}, \text { exp. }} \\
(\mathbf{k N})\end{array}$ & $\begin{array}{c}\text { Mid-span deflection at } \\
\mathbf{P}_{\mathrm{u}, \text { exp. }} \\
\boldsymbol{\delta}_{\mathrm{u}, \text { exp. }} \\
(\mathbf{m m}) \\
\end{array}$ & $\begin{array}{l}\text { Ultimate shear, } \\
\mathbf{V}_{\mathrm{u}, \text { exp. }} \\
(\mathbf{k N})\end{array}$ & $\begin{array}{c}\text { Ultimate moment, } \\
\mathbf{M}_{\mathrm{u}, \text { exp. }} \\
(\mathbf{k N m})\end{array}$ \\
\hline FS250-16 & 30.0 & 496.8 & 58.5 & 248.4 & 260.8 \\
\hline FS300-16 & 32.0 & 499.6 & 66.6 & 249.8 & 262.3 \\
\hline FS250-14 & 34.1 & 440.6 & 49.7 & 220.3 & 231.3 \\
\hline FS300-14 & 32.6 & 472.1 & 54.9 & 236.1 & 247.9 \\
\hline FS250-12 & 32.6 & 438.5 & 49.6 & 219.3 & 230.3 \\
\hline FS300-12 & 35.3 & 466.1 & 56.9 & 233.1 & 244.8 \\
\hline
\end{tabular}

From Table 2, it can be seen that the composite beam specimens manifested a significant values of ultimate shear and ultimate moment capacities. However, it is observed also that all specimens with a longitudinal spacing of $300 \mathrm{~mm}$ demonstrated higher ultimate shears and moments values as compared with those at spacing of $250 \mathrm{~mm}$. This shows that increase in the longitudinal spacing between the shear connectors played a role in influencing the ultimate shears and moments capacities of the composite specimens. A remarkable increase in the ultimate shears and moments capacities was noticed with a percentage increase of $5.5 \%$ between FS300-16 and FS300-14 and of $6.7 \%$ between FS300-16 and
FS300-12 respectively as presented in Table 3 . It is also noticed that an increase of $11.3 \%$ between FS250-16 and FS250-14 and of $11.7 \%$ between FS250-16 and FS250-12 was manifested by the composite specimens in terms of ultimate shear and moment capacities (see Table 3). This also shows that increase in the size of shear connector influenced the shear and moment carrying capacities of the composite beam specimens.

Table 3: Influence of shear connector spacing and size on shear and moment capacities

\begin{tabular}{|c|c|c|c|c|}
\hline Specimen ID & $\begin{array}{l}\text { Type of Shear } \\
\text { Connector }\end{array}$ & $\begin{array}{c}\text { Ultimate Shear, } \\
\mathbf{V}_{\mathbf{u}, \text { exp. }} \\
(\mathbf{k N})\end{array}$ & $\begin{array}{c}\text { Ultimate Moment, } \\
\mathbf{M}_{\mathrm{u}, \exp .} \\
(\mathbf{k N m})\end{array}$ & $\begin{array}{c}\text { Percentage increase } \\
(\%)\end{array}$ \\
\hline \multicolumn{5}{|c|}{$300 \mathrm{~mm}$ Spacing } \\
\hline FS300-14 & Bolt M14 & 236.1 & 247.9 & $\begin{array}{c}\text { FS16VsFS14 } \\
5.5\end{array}$ \\
\hline FS300-12 & Bolt M12 & 233.1 & 244.8 & $\begin{array}{c}\text { FS16VsFS12 } \\
6.7\end{array}$ \\
\hline \multicolumn{5}{|c|}{250 mm Spacing } \\
\hline FS250-16 & Bolt M16 & 248.4 & 260.8 & - \\
\hline FS250-14 & Bolt M14 & 220.3 & 231.3 & $\begin{array}{c}\text { FS16VsFS14 } \\
11.3\end{array}$ \\
\hline FS250-12 & Bolt M12 & 219.3 & 230.3 & $\begin{array}{c}\text { FS16VsFS12 } \\
11.7\end{array}$ \\
\hline
\end{tabular}

\subsection{Comparison between Experimental and Theoretical Results}

A comparison between experimental and theoretical results was conducted for the purpose of validation. The theoretical calculation was based on the well-known rigid plastic method of analysis of composite beam. Shear capacities $\left(Q_{u}\right)$ of bolted shear connec

tors were determined from push-out test conducted by [15], and the results were presented and discussed. The shear capacities $\left(Q_{u}\right)$ determined were used to evaluate the corresponding ultimate flexural capacities $\left(M_{u, \text { theory }}\right)$ for the composite beam specimens. The results of the comparative analysis are presented in Table 4 . From the results of the comparative analysis presented in Table 4, it can be observed that the experimental values agree well with the theoretical values. The result of web crippling capacity revealed that the design of the composite beam specimens is governed by the combination of bending and shear considering the two methods not by web crippling. 
Table 4: Comparison of Results between Experimental and Theoretical Values

\begin{tabular}{|c|c|c|c|c|c|c|c|c|c|c|c|}
\hline \multirow{3}{*}{$\begin{array}{l}\text { Specimen } \\
\text { ID }\end{array}$} & \multirow{2}{*}{\multicolumn{2}{|c|}{$\begin{array}{l}\text { Experimental } \\
\text { result }\end{array}$}} & \multicolumn{9}{|c|}{ Theoretical calculation result } \\
\hline & & & \multicolumn{4}{|c|}{ Interpolation method } & \multicolumn{4}{|c|}{ Stress block method } & \multirow{2}{*}{$\begin{array}{c}\text { Web crip- } \\
\text { pling } \\
\mathbf{R}_{\mathbf{w}, \mathbf{R d}} \\
(\mathbf{k N})\end{array}$} \\
\hline & $\begin{array}{l}\mathbf{V}_{\mathrm{u}, \text { exp. }} \\
(\mathbf{k N})\end{array}$ & $\begin{array}{l}M_{u, \text { exp. }} \\
(\mathbf{k N m})\end{array}$ & $\begin{array}{c}\mathbf{V}_{\mathrm{u}}, \\
\text { theory } \\
(\mathrm{kN}) \\
\end{array}$ & $\begin{array}{c}\mathbf{V}_{\mathbf{u}, \text { exp }} / \mathbf{V}_{\mathbf{u}}, \\
\text { theory }\end{array}$ & $\begin{array}{c}\mathbf{M}_{\mathrm{u}} \\
\text { theory } \\
(\mathbf{k N m})\end{array}$ & 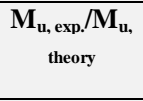 & $\begin{array}{c}\mathrm{V}_{\mathrm{u}} \\
\text { theory } \\
(\mathrm{kN})\end{array}$ & $\mathbf{V}_{\mathrm{u}, \exp } / \mathbf{V}_{\mathrm{u}}$ & $\begin{array}{c}\mathbf{M}_{\mathrm{u}} \\
\text { theory } \\
(\mathbf{k N m})\end{array}$ & $\underset{\text { theory }}{\mathbf{M}_{\mathrm{u}, \exp } / \mathbf{M}_{\mathbf{u}}}$ & \\
\hline FS250-16 & 248.4 & 260.8 & 242.5 & 1.02 & 247.1 & 1.06 & 269.1 & 0.92 & 270.2 & 0.97 & \multirow{7}{*}{296.9} \\
\hline FS300-16 & 249.8 & 262.3 & 232.6 & 1.07 & 236.0 & 1.11 & 267.0 & 0.94 & 268.5 & 0.98 & \\
\hline FS250-14 & 220.3 & 231.3 & 239.4 & 0.92 & 243.4 & 0.95 & 244.0 & 0.90 & 261.5 & 0.88 & \\
\hline FS300-14 & 236.1 & 247.9 & 232.0 & 1.02 & 235.9 & 1.05 & 237.1 & 1.00 & 255.1 & 0.97 & \\
\hline FS250-12 & 219.3 & 230.3 & 213.1 & 1.03 & 217.2 & 1.06 & 218.1 & 1.01 & 221.1 & 1.04 & \\
\hline FS300-12 & 233.1 & 244.8 & 207.2 & 1.13 & 211.3 & 1.16 & 212.2 & 1.10 & 229.5 & 1.07 & \\
\hline Mean & - & - & - & 1.03 & - & 1.07 & - & 0.98 & - & 0.99 & \\
\hline $\begin{array}{ll}\text { Standard } & \text { De- } \\
\text { viation } & \\
\end{array}$ & - & - & - & 0.07 & - & 0.07 & - & 0.07 & - & 0.07 & \\
\hline
\end{tabular}

For instance, the required shear for specimens FS250-16 and FS300-16 to fail under the combination of bending and shear is $242.5 \mathrm{kN}$ and $232.6 \mathrm{kN}$ respectively considering linear interpolation method; and for stress block method shears of $269.1 \mathrm{kN}$ and $267.0 \mathrm{kN}$ are required for the specimens to fail under the combination of bending and shear. Whereas, a shear load of $296.9 \mathrm{kN}$ is required for the same specimens to fail under web crippling. Therefore, from the analogy it clearly shows that web crippling does not influence the design of the composite beam specimens.

\section{Conclusion}

From the results of this study, the following conclusions can be drawn.

I. Experimental shear capacities $\left(\mathrm{V}_{\text {exp }}\right)$ were found to be in good agreement with the theoretical shear capacities $\left(\mathrm{V}_{\text {theory }}\right)$ with a mean and standard deviation of 1.03, 0.98 and $0.07,0.07$ for linear-interpolation and stress-block methods respectively.

II. Experimental moment capacities $\left(\mathrm{M}_{\exp }\right)$ were found to be in good agreement with the theoretical moment capacities $\left(\mathrm{M}_{\text {theo- }}\right.$ ry) with a mean and standard deviation of 1.07, 0.99 and 0.07 , 0.07 for linear-interpolation and stress-block methods respectively.

III. Strength capacities of the composite beam specimens were found to have increased with an increase in the size and longitudinal spacing between the shear connectors.

IV. The design of the composite beam specimens is shown to be governed by the combination of bending and shear considering the two methods not by web crippling.

\section{Acknowledgement}

The authors gratefully acknowledge the support provided by Kano University of Science \& Technology, Wudil (KUST) and Universiti Teknologi Malaysia (UTM VOT No. Q.J130000.2522.18H02).

\section{References}

[1] Pavlovic, M., Spremic, M., Markovic, Z., Budevac, D. \& Veljkovic, M., "Recent research of shear connection in prefabricated steelconcrete composite beams", Istrazivanja i projektovanja za privredu, Vol.12, (2014), pp:75-80.

[2] Kim, B., Howard, D. W. \& Cairns, R., "The behaviour of through deck welded shear connectors: an experimental and numerical study", Journal of Constructional Steel Research, Vol.57, (2001), pp:1359-1380.

[3] Prakash, A., Anandavalli, N., K. Madheswaran, C. \& Lakshmanan, N., "Modified Push-out Tests for Determining Shear Strength and Stiffness of HSS Stud Connector-Experimental Study", International Journal of Composite Materials, Vol.2,No.3, (2012), pp:22-31.

[4] Pallarés, L., \& Hajjar, J. F., "Headed steel stud anchors in composite structures, Part I: Shear", Journal of Constructional Steel Research, Vol.66, No. 2, (2010), pp:198-212.

[5] Eurocode 4, EN1994., "Design of composite steel and concrete structures- Part 1-1", General rules and rules for buildings. European Committee for Standardization, Brussels, (2004).

[6] Ollgaard, J. G., Slutter, R. G., \& Fisher, J. W., "Shear strength of stud connectors in lightweight and normal weight concrete", AISC Engineering Journal, Vol.1 No.1, (1971).

[7] Lakkavalli, B. S. \& Liu, Y., "Experimental study of composite cold-formed steel C-section floor joists", Journal of Constructional Steel Research, Vol.62, No.10, (2006), pp: 995-1006.

[8] Lam, D., "Capacities of headed stud shear connectors in composite steel beams with precast hollowcore slabs", Journal of Constructional Steel Research, Vol.63, No.9, (2007), pp:1160-1174.

[9] Smith, A. L., \& Couchman, G. H., "Strength and ductility of headed stud shear connectors in profiled steel sheeting", Journal of Constructional Steel Research, Vol.66, No.6, (2010), pp:748-754.

[10] Kwon, G., Engelhardt, M. D. \& Klingner, R. E., "Behavior of postinstalled shear connectors under static and fatigue loading", Journal of Constructional Steel Research, Vol.66, No.4, (2010), pp:532-541. Irwan, J. M., Hanizah, A. H., Azmi, I., \& Koh, H. B., "Large-scale test of symmetric Cold-Formed Steel (CFS) - concrete composite beams with BTTST enhancement", Journal of Constructional Steel Research, Vol.67, (2011), pp:720-726.

[12] Pavlović, M., Marković, Z., Veljković, M. \& Buđevac, D., "Bolted shear connectors vs. headed studs behaviour in push-out tests", Journal of Constructional Steel Research, Vol.88, (2013), pp:134149.

[13] Bamaga, S. O. \& Tahir, M. M., "Towards Light-Weight Composite Construction: Innovative Shear Connector for Composite Beams", Applied Mechanics and Materials, Vol.351-352), (2013), pp: 427433.

[14] Alenezi, K., Talal, A., Tahir, M. M., Mohamed Ragaee, Badr K., \& Bamaga S. O., "Strengthen of Cold-Formed Steel Column with Ferrocement Jacket: Push out Tests" International Journal of Civil, Architectural Science and Engineering, Vol.7, No.11, (2013), pp:262272.

[15] Lawan, M. M., Tahir, M. M., \& Mirza, J., "Bolted Shear Connectors Performance in Self-Compacting Concrete Integrated with Cold-Formed Steel Section", Latin American Journal of Solids and Structures, Vol.13, (2016), pp:731-749. 